\title{
New Forms of Migration into the European South: Challenges for Citizenship and Governance - the Portuguese Case
}

\author{
Maria Lucinda Fonseca, ${ }^{1 *}$ Maria José Caldeira ${ }^{2}$ and Alina Esteves ${ }^{1}$ \\ ${ }^{1}$ Centre of Geographical Studies, Faculty of Arts, Lisbon University, Lisboa, Portugal \\ ${ }^{2}$ Institute of Social Studies, Minho University, Campus de Azurém, 4810 Guimarães, \\ Portugal
}

\section{ABSTRACT}

Since the mid-1980s, Portugal has altered its position in the international migration context. It is no longer exclusively an emigration country but has also become a receiving nation, hosting people from its former African colonies, and more recently from Brazil and Eastern Europe. This has caused significant changes in Portuguese society, which is nowadays socially more diverse and ethnically richer. This paper identifies the most important challenges to citizenship and governance in Portugal, focusing on: (a) the changes in the national laws regulating immigration; (b) the measures adopted by central government to fight discrimination; and (c) the growing social exclusion faced by many immigrants. Among the adopted measures, the new law regulating the entry and permanence of foreigners in Portugal, the establishment of a High Commissioner for Immigration and Ethnic Minorities (ACIME), the growing role of immigrants' associations, and the responsibilities transferred to local authorities are closely analysed. Drawing on analysis of interviews and questionnaires addressed to civil servants working in departments related to immigration as well as

\footnotetext{
* Correspondence to: M. L. Fonseca, Centre of Geographical Studies, Faculty of Arts, Lisbon University, 1600214 Lisboa, Portugal.

Email: lfonseca@reitoria.ul.pt
}

on reports published by municipalities in the Lisbon Metropolitan Area (LMA), the article also investigates the strategies adopted by local authorities to promote the successful integration of immigrants. The evidence indicates that there is a growing feeling among local authorities that their resources should be oriented to work with the citizens and not just for the citizens. To guarantee future sustainable development, citizens, regardless of their geographical origin, should have a say in the decision-making processes at a local level. Copyright (C) 2002 John Wiley \& Sons, Ltd.

Received 8 March 2001; revised 10 July 2001; accepted 3 September 2001

Keywords: immigration to Portugal; Lisbon Metropolitan Area; urban governance; local authorities

\section{INTRODUCTION}

7 he migratory tradition of Southern Europe is a distinguishing factor setting these countries apart from those of Northern Europe. The progressive change from emigration to immigration countries, after the beginning of the 1980s, has been much discussed in recent years by migration scholars (see, for example, King and Rybaczuk, 1993; King and Black, 1997; Castles and Miller, 1998; King et al., 2000; Solé, 2001).

In the history of Southern European coun- 
tries, the notion of immigration was, until very recently, more frequently associated with their fellow citizens who went to Northern Europe in order to escape poverty and fight for a better life, rather than with foreigners living in their countries. The inversion of the migratory route in the new immigration countries is, therefore, a mirror reflecting the host societies (Ritaine, 1999: 3) and causes some difficulties in the definition of national identity. These societies, for the first time in their history, facing an unprecedented ethnic, social and cultural diversity, have been compelled to question their national identity and their concept of citizenship.

The emergence of immigration as a political issue in Southern Europe happened much later and in substantially different conditions from those between the Second World War and the 1970s in the northwestern European countries. The politicisation of immigration in the Northern Mediterranean is closely associated with the European integration process and, until recently, its main goal was to control the borders and to limit the entrance of non-EU citizens. This means that the emphasis given to immigration as a public problem at the beginning of the 1990s in Portugal, Spain, Italy and Greece is more a consequence of the Schengen Agreement than of the volume of foreign citizens living in these countries. ${ }^{1}$ However, instead of reducing the entry of non-EU citizens, the limitation of legal entries to the Schengen area countries ${ }^{2}$ had the opposite effect - it induced an increase in illegal immigration and the development of international labour traffic networks (Baganha and Malheiros, 2000). In fact, as King (2000: 13) pointed out, this clandestine migration derives from the contradiction between the idea of reducing the entries of immigrants coming from poor countries, and the global economic framework in which the growing external migratory pressure (push factors) combine with sector deficits in the internal labour market (pull factors) to force the import of labour (Pugliese, 1993; King and Rybaczuk, 1993; Mingione, 1995; Iosifides and King, 1996; Frangouli-Papantoniou, 1998 Reyneri, 1998; Baganha et al., 1999).

The 'illegalization' of migration and the development of international trafficking net- works is also responsible for the more frequent association made between immigration and the increase of terrorism and organised crime at the international level, and the rise of xenophobic and racist attitudes towards migrant communities (Montanari, 2000).

In this context, the purpose of this paper, using the Portuguese example, is to reflect on the new challenges for citizenship and governance, identify the main problems and discuss some of the intervention strategies that may invert the trend of reinforcing marginalisation and social exclusion mechanisms associated with the increasing immigration and ethnic and cultural diversity of Southern Europe, mainly in urban areas. The paper begins by giving an overview of recent immigration into Portugal: the geographical pattern and character of stocks and flows of migrants. Then follows a reflection on the immigrant participation in Portuguese society. Thirdly, attention will be given to national state responses to immigration. Fourthly, considering the huge concentration of immigrants and ethnic minorities in the Lisbon Metropolitan Area (LMA), the role of local authorities in hosting these people will be analysed. Finally, some concluding remarks on the new challenges for citizenship and local governance, particularly in urban areas where immigrants live, will be presented.

\section{RECENT IMMIGRATION INTO PORTUGAL: AN OVERVIEW}

In order to ensure the greatest possible accuracy in interpreting and handling the information contained in this paper, it is necessary to clarify the meaning of two basic concepts: immigrants and ethnic minorities. The term 'immigrants' refers to foreign nationals living in Portugal. Ethnic minorities are defined as all people, independent of their nationality and place of birth, who share an ethnic background different to the one shared by the majority of the population. We use this definition because in Portugal, members of the non-dominant ethnic groups are a quantitative minority and mainly because, in day-to-day practices, they suffer from discrimination due to their ethnic background. 


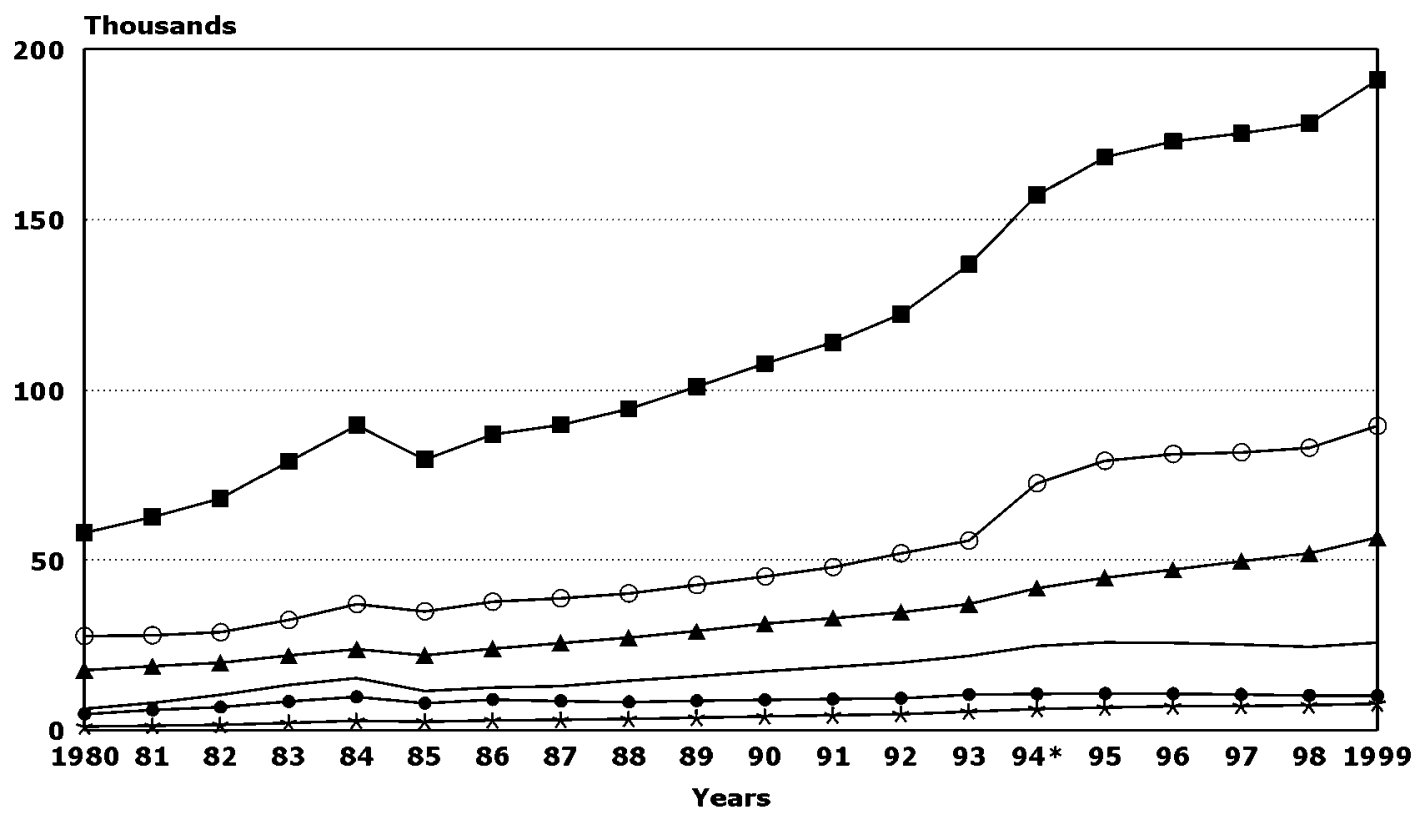

- Total $\ominus$ Africa - North America - South America *Asia $\star$ Europe

Figure 1. Evolution of the legally resident foreign population in Portugal, by continent of origin, 1980-99. *The statistics for 1994 include the special regularisation process (1992/93). Source: INE - Estatísticas Demográficas, 1980-1999, Lisbon.

Until the mid-1970s, immigration flows into Portugal were extremely small. From then on, several internal and international factors converged and contributed to changing Portugal's migratory tradition. The establishment of a democratic regime in 1974, the African decolonisation process, the internationalisation and modernisation of the Portuguese economy and the beginning of EU integration (all in a context of recession and economic restructuring in more developed capitalist countries) are some of the most important elements in the inversion of the Portuguese position in the international migration system. Emigration declined, and immigration, until then extremely limited, began a significant growth phase, mainly due to the forced migration of half a million people to Portugal because of the independence of former African colonies. As a consequence of the decolonisation process, many of these refugees lost their Portuguese nationality due to their African origin (DecreeLaw no. 308-A/75, 24 July), and consequently were excluded from social benefits and poli- tical participation in Portuguese society. The sudden loss of Portuguese nationality affected the immigrants born in the former African colonies who were not descendants, up to the third degree, of people born in Portugal, or who until the Revolution of 25 April 1974 had not been living for more than five years in Portugal. The settlement of refugees from the former colonies in Portugal had an important role in the later immigration coming from these countries, establishing family, social and ethnic community networks.

Figure 1 shows the profile of increasing foreign residents in Portugal since 1980. Immigration, mainly for economic reasons, was intensified with the arrival of newcomers from a wider range of countries, many of whom entered the country illegally. Europe is, after Africa, the origin continent producing most immigrants $(56,731)$, representing, in $1999,29.7 \%$ of a total of 190,896 foreign citizens of Portugal. America occupies the third position, being responsible for $20.9 \%$ of foreigners who by the end of 1999 had a residence permit 


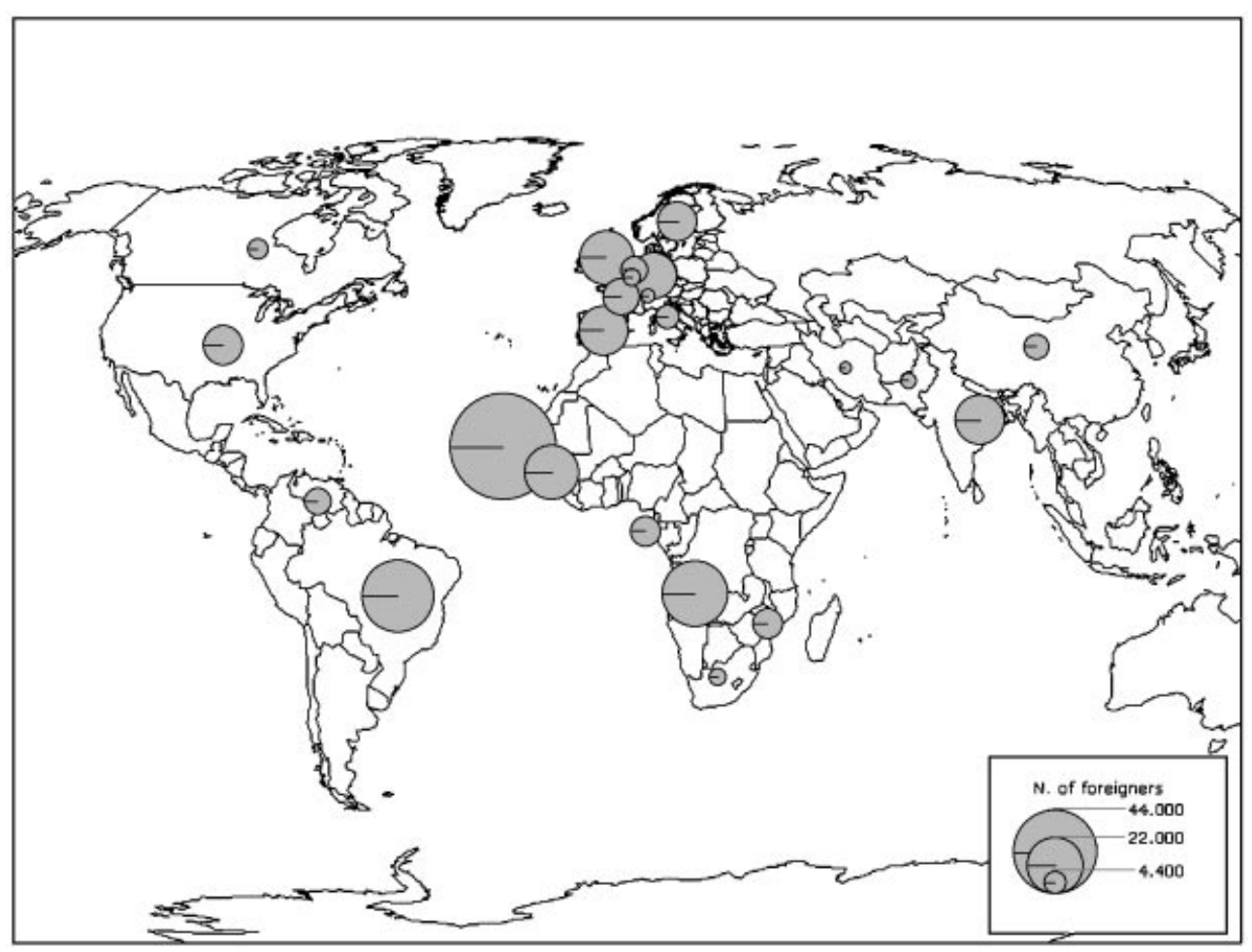

Figure 2. Origins of foreign citizens with a residence permit living in Portugal (31/12/1999). Only the sending countries with 500 or more immigrants living in Portugal were considered. Source: Foreigners and Borders Office, Lisbon.

to live in Portugal.

In a more detailed observation, the countries from the Portuguese Language Community (PALOP and Brazil) account for $55.4 \%$ of the stock of documented foreign residents in Portugal (Fig. 2). This fact suggests that until the end of the 1990s, immigration to Portugal was closely linked to the country's colonial past.

Recent estimations widely revealed in the printed media, radio and television, mention a huge non-documented migratory wave coming from Eastern Europe, namely from the Ukraine, Moldova and Romania, and to a lesser extent from Russia and Bulgaria. The results of the legalisation campaign that began in January 2001 confirm this trend, because citizens coming from the five above-mentioned Eastern European countries accounted for 53\% of the 94,947 permanence permits given by the Foreigners and Borders Office (SEF) up to 4 September 2001.

\section{IMMIGRANT PARTICIPATION IN SOCIETY}

As stated by Castles and Davidson (2000), belonging to a modern democratic society is marked by citizen status. Class, gender, ethnicity, race, religion or any other criteria-based discrimination has always meant that some people did not enjoy the rights of full citizens. Therefore, the participation of previously excluded groups has been seen as the key to the democratisation of societies.

The present economic globalisation framework and the increase and diversification of international migrations bring forth new challenges to citizenship and to the basis of the nation-state. More and more people live outside their home country and are thus excluded from political participation in the places where they live. Resulting from the growing ethnic and cultural heterogeneity of the resident population in Western democratic states, the concept of citizenship based on the individual 
belonging to a sole nation-state and a sole collective has been challenged. Recognising the equality of all citizens in the face of the law is not enough. In order that the State can be inclusive, it is essential to find a new citizenship concept that ensures individual equality, recognising also collective differences and considering the citizens' multiple identities (Castles and Davidson, 2000).

Despite important changes in international law and political contexts mainly in Europe, which aim to bring the economic, social and political rights of foreigners closer to those of nationals and to make the acceptance of multiple citizenship more flexible, in fact, in day-to-day practice there are anti-immigrant predispositions, including racism (Arango, 1998). Even when documented immigrants enjoy the same civil rights as nationals, they are far from having full citizenship, because they neither have political rights, nor do they enjoy equality of social rights. The poverty and social marginality in which many immigrants and ethnic minorities live, with simultaneous intolerance towards their religious and cultural practices, are evident testimony of the persistence in European societies of different exclusion forms, opposing the basic principles of modern democracies. Thus, the openness of the host societies to cultural diversity and to the participation of immigrants and ethnic minorities in policy-making is an essential condition for the development of new policy and social organisation forms that ensure the equality of individual rights, promoting simultaneously an intercultural dialogue and social cohesion. This practice of citizenship in a wider sense is based on the conjugation of an institutional architecture of the host society that accepts and encourages the participation of immigrants and ethnic minorities in society, and also on the mobilisation of organisations able to defend immigrants' rights so that all members of the civil society can feel integrated in their environment (Penninx, 2000).

In Portugal, with immigration being a relatively new phenomenon, the debate on the civil inclusion of immigrants has only recently reached the political agenda. The recognition of the voting rights of foreign citizens in local elections only goes back to 1996. Moreover, the juridical regime of Im- migrants' Associations, existing since the 1970s, was only approved by Parliament in 1999 (Decree-Law no. 115/99). According to Soysal (1994), the participation of immigrants in voluntary associations tends to reproduce the dominant matrix of the host society. Portugal has a very weak civil society, where estrangement and even suspicion towards formal organisation and dynamics are dominant. It traditionally has a very passive posture towards the exercise of rights and duties, and its distrust of democratic structures has been growing over the years.

In the case of immigrants living in Portugal, according to Marques et al. (1999), the empirical evidence also seems to confirm the trend pointed out by Soysal, because immigrant participation in voluntary associations, similarly to the Portuguese population, is very limited. The lack of political participation among immigrants is aggravated by a lack of information about their rights and responsibilities as citizens. High illiteracy rates, little tradition of democratic participation in the countries of origin, and few municipal offices providing legal advice and information about civic rights, are some of the factors behind this problem. Despite this, it is important to stress that the development of migrants' associations had a major boost after the mid-1990s, formally recognised for their role as development agents of migrant communities by national and some local political institutions.

Although immigration into Portugal is a recent phenomenon, it is possible to identify three stages in the evolution of the migrants' associations. The first stage began in the mid1970s, after the arrival of a high number of refugees from the former African colonies, and gathered strength during the 1980s. In the initial stage migrants' associations had a rather informal nature and were dispersed in the LMA in the neighbourhoods inhabited by immigrants from PALOP, especially from Cape Verde. Their main concern was to facilitate the hosting of relatives, friends and countrymen who arrived in Portugal, helping them to find a place to live, a job and a residence permit, solving daily problems and promoting cultural activities typical to the sending countries.

Many of these associations were boosted, 
after the 1974 Revolution, by the boom in popular organisations that operated in the community. Thus, the first migrants' associations were set up as neighbourhood commissions and had an important role in the improvement of living conditions, mainly in basic infrastructure (water supply, sewage system, street paving, and so on). Moreover, the importance of popular literacy campaigns after 1974 also led to a literacy movement, developed by several migrants' associations and supported by the Ministry of Education, oriented to the African immigrants with difficulties in commanding the Portuguese language (Albuquerque et al., 2000a).

The first years of the 1990s marked a major growth period in the number of associations and the beginning of a new phase in which they achieved relevance in the political sphere, namely in the debate around immigrants' citizenship rights. The origin of this mobilisation was based on factors related to immigration control imposed by the EU, the absence of an integration policy for immigrants, and the growing non-documented immigration.

However, it is important to stress that after 1992, as a consequence of the first extraordinary regularisation process, decisive steps to politicise immigration and ethnicity were taken. According to Machado (1992), the 1992/93 extraordinary regularisation represented 'the zero degree of ethnicity politicisation', not only because the State recognised migrants' associations as interlocutors during the regularisation process, but also because associations widened their civic intervention area and reinforced their capacity to fight for the social and political rights of immigrants.

The collective mobilisation of immigrants' associations had a new boost in 1995 when a young Portuguese man of Cape Verdean origin was killed by a group of skinheads in a neighbourhood well known for its nightclubs and restaurants near the historical centre of Lisbon. Widely publicised by the media, this event unleashed an intense wave of protest on the part of African and Brazilian immigrants' associations, as well as anti-racist and human rights associations and agencies of civil society. Immigrants' associations changed gradually from a clear intervention based on immediate assistance to a wider sphere of social and political intervention. This is illustrated in the more professional attitude of immigrants' associations and in the stronger affiliation to some political parties, namely the Socialist Party, which at that time was the main opposition party to the centre-right Social Democratic government.

When the Socialist Party came into power in October 1995, there was a change in the immigration policy of Portugal. This was illustrated in the relationship between immigrants' associations and other agencies of Portuguese civil society that directly or indirectly fight for the rights of immigrants and their offspring. The establishment of a High Commissioner for Immigration and Ethnic Minorities (ACIME) in 1996 represented an extremely important step in the consolidation of immigrants' associations, as well as their formal recognition as mediators in the relationship with the Government and the migrant communities. As a result, the associations have a seat on the Consultative Council for Immigration Issues and also on the Commission for Equality and Against Racial Discrimination.

Since the mid-1990s, immigrants' associations have been reinforcing their role as partners of other public and private institutions, with national and EU scope, developing initiatives and projects with social goals. A few examples are the Integrate Operational Initiative, YOUTHSTART, HORIZON, NOW, URBAN I and II, as well as the LIA Initiative and ELAINE network.

All in all, as Albuquerque et al. (2000b) stressed, immigrant associations have been focusing their action in three fundamental domains:

- Social-economic - non-formal educational activities for children and teenagers, support for the ageing population, training, healthcare, enhancement of their neighbourhoods and support to rehousing processes, often establishing the connection between communities and local authorities.

- Cultural - promoting cultural activities that preserve and pass to the next generation the cultural identity of the origin country (music, dance, mother tongue, etc.).

- Political - information on the rights of immigrants and representation of migrant 
communities in the dialogue with central government, local authorities and other relevant partners.

After overcoming a first phase of extreme dispersion and fragmentation, the present trend is for the migrant associations to achieve a more professional attitude and a higher degree of politicisation, mainly in the LMA, because Lisbon is the national capital and it accounts for more than half of the immigrants settled in Portugal.

\section{NATIONAL STATE RESPONSES TO IMMIGRATION}

As already mentioned, immigration policy in Portugal appeared quite late, and it is mainly the result of the European integration process and the international dispositions that protect the rights of immigrants in the framework of the Council of Europe, the World Labour Organisation and the United Nations.

The law regulating the entry, permanence, exit and withdrawal of foreign citizens adopts the generic dispositions found in the Schengen Agreement (1985), the Convention Agreement (1990) and the connected dispositions included in the Amsterdam Treaty (1999). Despite that, it also contains some signs of the colonial heritage, expressed in the positive discrimination towards immigrants coming from PALOP and Brazil, when compared with foreign citizens from non-EU countries, thus reflecting the desire that Portuguese authorities have to preserve the historical ties and agreements with former colonies (Dupraz and Vieira, 1999). The positive discrimination towards immigrants from these countries is present in the Nationality Law (Law no. 25/94), in the two extraordinary regularisation campaigns of undocumented migrants of 1992/93 and 1996, and in the Decree-Law regulating the entry, permanence, exit and withdrawal of foreign citizens in Portuguese territory (Decree-Law no. 59/93, revised by the Decree-Law no. 4/ 2001). As examples of the positive discrimination measures for foreigners coming from Portuguese-speaking countries, one can mention:

(1) regarding nationality by birth, those who are born on Portuguese national territory may be considered Portuguese if their parents are foreigners who have been legally residing in Portugal for at least six years if they came from a Portuguesespeaking country, or ten years if from another non-EU country.

(2) regarding acquisition of Portuguese nationality through the process of naturalisation, petitioners have to have maintained legal residence in Portugal for at least six years if they are from a Portuguese-speaking country, or ten years in other cases.

As far as the rights of immigrants are concerned, Portuguese law can be considered extremely positive. In the $13^{\text {th }}$ and $15^{\text {th }}$ articles of the Portuguese Constitution the principle of equality among citizens is recognised, and Portuguese and legal foreign residents are treated equally and have similar rights - civil, social and economic - except for the political participation right. Moreover, Law no. 134/99 (28 August) forbids discrimination based on race, nationality or ethnicity.

The political participation right is considered in the Portuguese Constitution and it is possible to give active (the right to be elected) and passive (the right to vote) electoral rights to foreign documented residents, in the elections for local authorities. The recognition of the right to take part in local elections was established by Law no. 56/96 (4 September). EU nationals, citizens from Portuguese-speaking countries with legal residence for more than two years, and other foreigners with legal residence for more than three years, are allowed to vote in local elections. According to the same law, and respecting the reciprocity principle, citizens from Portuguese-speaking countries who have been living in Portugal for more than four years can also be elected in local elections. The same applies to citizens from other countries who have been living in Portugal for more than five years. Today, apart from EU citizens, only those from Brazil, Cape Verde, Peru and Uruguay are entitled to vote and run for office. ${ }^{3}$ Nationals from Argentina, Chile, Estonia, Israel, Norway and Venezuela can only vote. Brazilians with a special status of equality of rights and duties can also vote for the Portuguese Parliament and in the national referenda (Leitão, 2000; Baganha et 
al., 2000).

Experience has shown that restrictions imposed by European countries on immigration, both by Northwestern Europeans, and more recently, by Southern Europeans, are completely inefficient. The main consequence is the development of international labour trafficking networks, an increase in organised crime and a fertile environment for the increase of poverty, social exclusion, inter-ethnic conflicts and the upsurge of xenophobic and racist attitudes on the part of some groups in the host societies. Portugal does not escape this situation. Although there were two extraordinary regularisation campaigns for non-documented immigrants, the first in 1992/93 and the second in 1996, the problem of clandestine immigration persists and tends to assume new configurations.

The two extraordinary regularisation campaigns were set up to legalise foreign citizens of non-EU countries residing illegally in Portugal who could support themselves. In the first campaign, of the 39,000 applications, only 16,000 people received residence permits. In the 1996 regularisation process, 35,000 requests were handed in and 90\% received a residence permit. The immigrants from Portuguese-speaking countries benefited in both campaigns from easier conditions when compared with nationals from other countries.

The recent revision of the law on the permanence of foreigners in Portugal (Decree-Law no. 4/2001, 10 January), allowing the regularisation of non-documented immigrants and introducing heavy penalties for employers who employ illegal foreigners, has the indisputable merit of forcing employers to write down labour contracts and therefore to combat exploitation, marginalisation and social exclusion practices associated with nondocumented immigration. However, one fears that being unable to satisfy the present demand for labour in Portugal, through bilateral agreements with the origin countries, the new law may have the opposite result of widening the scope of action of labour traffickers, namely to selling or promising to sell labour contracts. A significant piece of news published in the Expresso newspaper (28 April 2001) reported that in the historical centre of Lisbon (in Rossio and Figueira squares) work-

Copyright (C) 2002 John Wiley \& Sons, Ltd. ing contracts were sold to immigrants for 1,250 Euros.

With respect to Portuguese immigration policy, it is important to mention a group of measures and actions that aim to facilitate the integration of immigrants into Portuguese society. Of these, the following are of interest (Fonseca, 2000):

(1) The establishment, in February 1996, of the High Commissioner for Immigration and Ethnic Minorities (ACIME) who is responsible for promoting the improvement in living conditions of immigrants and ethnic minorities and their inclusion in Portuguese society, while respecting their identity and culture. The ACIME works in collaboration with immigrants' associations, members of ethnic minorities and non-governmental organisations (NGOs), in order to promote actions and design policies to eradicate the main causes of social exclusion, and to offer advice in dealing with legal and bureaucratic problems. The ACIME is appointed by the Prime Minister and reports directly to him.

(2) The access of immigrant families living in shanty towns in the Lisbon and Oporto Metropolitan Areas to special housing schemes (known as PER and PER Families) on an equal footing with Portuguese citizens. PER (Programa Especial de Realojamento / Special Rehousing Programme) is a scheme based on a contract between the government and the metropolitan municipalities which aims to eradicate shanty housing by 2001. PER Families allows people to buy a dwelling for permanent habitation or to restore one owned elsewhere, on condition that it will be used as the family's permanent residence.

(3) Immigrant families legally residing in Portugal can also benefit, under the same conditions as Portuguese families, from the Guaranteed Minimum Income to combat poverty and social exclusion. Apart from financial support, the policy includes housing and health initiatives, educational programmes, employment services, and opportunities for professional training.

Int. J. Popul. Geogr. 8, 135-152 (2002) 


\section{THE ROLE OF LOCAL AUTHORITIES IN HOSTING IMMIGRANTS}

\section{Challenges Faced by Immigrants}

Local authorities have a significant role in hosting and promoting the integration of immigrants because they deal directly with people's difficulties, anxieties and daily problems. Municipal authorities are supposed to help all citizens to find a place in the local community and to develop a sense of belonging in that particular community and in Portuguese society in general. Municipalities are the entities that bring national policies down to the local level and put them into practice (Ruivo, 2000). These are not just immigration and hosting policies, but also housing, health and social policies. Therefore, they can assess the results of their implementation and send feedback to the government with a package of new proposals and initiatives to be adopted (Lapeyronnie, 1992).

After the 1974 Revolution, Portuguese municipalities were entitled to considerable autonomy from the national state. In terms of financing, the budget of the 308 Portuguese municipalities is made up of an annual amount of money transferred from central government (variable according to the resident population, geographical area, number of boroughs, etc.) and of local taxes on vehicles, shops, buildings, sewage system, water supply, and so on. According to the Portuguese Constitution (Article no. 240) and the Law of Local Finances (Law no. 42/98, 6 August 1998), local authorities enjoy autonomy in the management of their revenue.

When immigrants arrive in a new country they are confronted with a series of challenges and new situations that may hinder their prospects of success. It is difficult to estimate what might be considered the most serious problem that immigrants have to face when they arrive in Portugal, because citizens coming from diverse geographical origins and social backgrounds have different hopes and expectations about their future lives. It is reasonable to start with housing, because this is one of the basic needs of every human being. The Portuguese housing market is extremely expensive and dwellings reach even higher prices in the metropolitan areas where demand is more intense and competitive. For example, the acquisition price of a three-room apartment in a Lisbon suburb can vary between 100,000 and 175,000 Euros, when the Portuguese minimum salary is only 335 Euros per month. Renting may cost between one and two minimum salaries per month for this kind of flat. In addition, it can be more difficult for a foreign citizen with a small monthly income to obtain a bank loan due to the prejudiced attitudes of some credit institutions. The renting market is relatively new, and again the costs are unbearable for families with small incomes. Many Portuguese and foreign-born families had, until the late 1980s and early 1990s, been living in shanty neighbourhoods whose origins go back to the 1960s when the population living in metropolitan areas grew very rapidly without the corresponding provision of proper housing (Malheiros, 2000). Therefore, due to the inability to support these rents, the State and the local authorities had to build social housing, adjusting the monthly rent to the family's budget. Again cultural and racial prejudices can play an important role when finding a place to rent, because besides being foreigners, people often speak a 'strange' language, dress in an unusual fashion, or have different complexions from the dominant majority.

Employment insecurity is another problem often faced by immigrants in Portugal. Although unemployment rates among foreign citizens are low, many of them work without a legal contract (Malheiros, 1998). This situation is possible because some of the jobs performed help, to a certain extent, to conceal their 'illegality'. Men who work in civil construction often move between construction sites and yards, making it difficult for labour supervisors to detect irregularities. Sometimes, inspections are simply not carried out because public works have to be finished on time and delays are not tolerated. Many women work as domestic servants for Portuguese families, and being inside a private dwelling presents enormous difficulties for inspectors who wish to supervise documents. Moreover, workers without a legal contract do not benefit from social and health assistance in case of a labour accident. Unscrupulous employers may not 


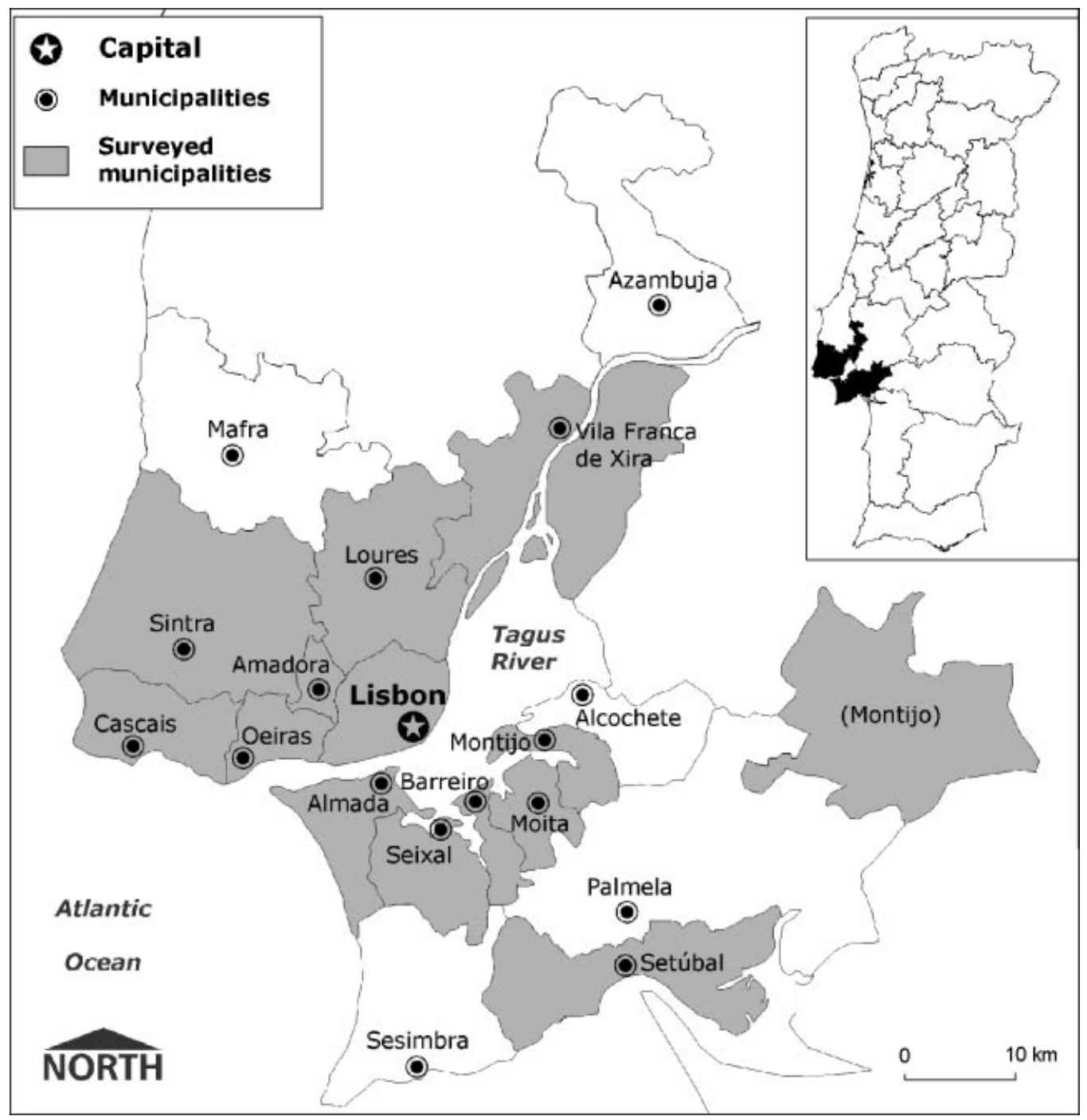

Figure 3. Surveyed municipalities in the Lisbon Metropolitan Area.

pay the wages that workers are entitled to, and can easily fire them if they dare to complain to trade unions. Needless to say, this vulnerability of foreign workers is reinforced when the absence of a working contract is added to the lack of a residence permit. However, with the new law on the entry, permanence, departure and withdrawal of foreigners from Portuguese territory, new rules are being implemented to break down illegal work. Immigrants with a labour contract can live in the country for a five-year period, renewable every year.

Having access to education is important for future active citizenship, and as noted by Faulks, 'Citizenship is an active rather passive status' (2000: 4). The main problem with education is not really the access of immigrants' children to school, but rather their school failure and drop-out record. Considering that almost half of the foreigners with residence permits living in Portugal come from an African country with Portuguese as the official language $(45 \%)$, in principle the vast majority of the offspring of immigrants should speak Portuguese. However, native African dialects are often used at home. Thus, when 6- 


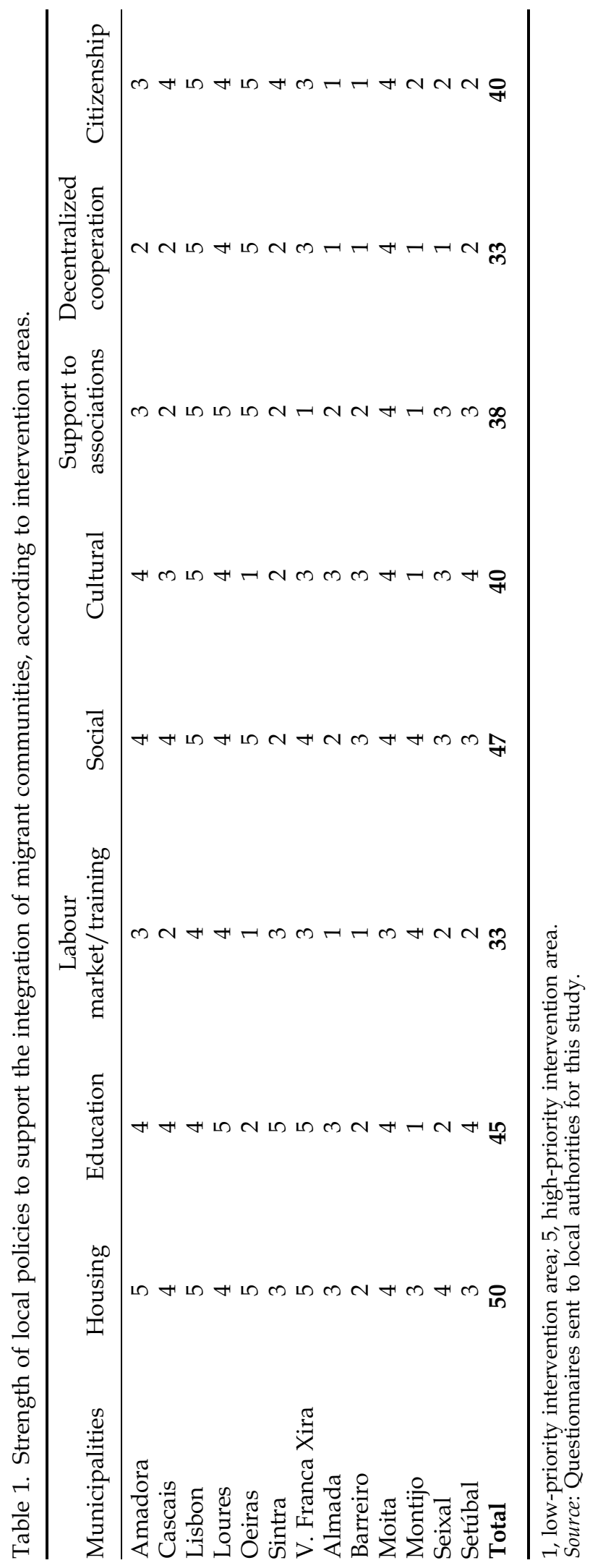


and 7-year-old children attend school classes it is extremely difficult for them to follow what is taught. Moreover, some of the subjects are not considered very attractive and are far from the students' interests. In addition, children do not receive much help from parents with homework, either because they lack the cultural capital needed or because of time constraints. Due to high failure rates, youngsters are often only kept inside the education system for the nine years of compulsory education. This gives them very little preparation to find a skilled or well-paid job.

The category of social problems is extremely wide, and difficulties of this nature may result both from the physical features of neighbourhoods and from individual circumstances. On the one hand, there is a lack of kindergartens and other pre-school nurseries where mothers can leave their children during the day, instead of leaving them with older siblings, neighbours or friends. They lead extremely hard lives, and better social infrastructure to help them with the children would be welcomed. Youth and sports clubs are also structures that help to keep youngsters off the streets and busy with more constructive activities. On the other hand, the irregular situation of many immigrants hinders their use of the existing structures subsidised by Social Security, for the simple reason that they fail to present the necessary documentation.

\section{Local State Responses to Immigration: The Case of Lisbon}

The Lisbon Metropolitan Area (LMA) is the largest Portuguese metropolitan area. It comprises 18 municipalities and approximately $25 \%$ of the 10 million Portuguese people. Five municipalities were excluded from our research because the percentage of immigrants in their population was extremely small (less than 1\%). Therefore, only 13 municipalities were taken into account (Fig. 3).

A questionnaire with three sets of questions was sent to these municipalities between February and April 2001, including questions on the kind of relationship between the local authorities and immigrants' associations (proactive, reactive, frequent, non-existent), the participation of immigrants in decision-making and consultative councils, and the existence of specific boards working with and for the immigrants. The last group included a table with eight areas of intervention, ranging from housing, labour market and training to cultural issues and citizenship. The areas were rated from 1 to 5 and examples of good practice, when possible, were asked for. In order to complement this information, interviews were carried out in ten municipalities with civil servants in charge of local cabinets and departments dealing with cultural issues, housing, social support and immigration.

After analysing the results obtained from the questionnaires, it can be noted that housing is still the main concern amongst most local authorities in the LMA (Table 1). The limitations of housing markets, and the relational networks already established in this territory, have been leading immigrants to shanty neighbourhoods that are now being demolished and replaced by social housing.

As mentioned earlier, in order to answer this challenge, municipal authorities and central government have been implementing a Special Rehousing Programme (PER) to eliminate shacks and build new residential blocks by the end of 2001. Its implementation has been the main solution for the housing problem, not only among immigrants, but also among lowincome Portuguese families.

In the LMA, the PER covers 113,701 inhabitants, representing $4.5 \%$ of people living in this area in 1991. Although there are no detailed data according to ethnic group, the distribution of registered people according to nationality allows us to see that immigrants from PALOP countries are largely over-represented in the population to be rehoused. They hold a share that is seven times higher than their proportion in the LMA in 1991 (20.2\% and 2.8\% respectively). It is also important to stress that this figure would be even higher if the Portuguese citizens of African origin were taken into account, namely the children of immigrants born in Portugal.

On a second level, and related to the housing issue, one can find social support and education initiatives developed in order to solve or minimise situations of social, economic and cultural exclusion, or to prevent situations of 
future marginality. Among the social support measures, the guaranteed minimum income must be emphasised. Although it is an initiative from central government, extended to every family in need, it is the civil servants from the municipal authorities who often give information, clear up problems and receive the documentation in the local boroughs. Each municipality has at least a Local Follow-up Commission (LFC) whose task is to study the requests handed in, select the eligible beneficiaries, and give advice on what kind of social integration programme the individuals or the families must follow. Each of these Commissions must necessarily include representatives from the local Social Security Centre, Job Centre, Ministry of Education and Public Health Service. When required, the representatives of each local authority, NGO, trade union and entrepreneurs' association also have the right to be members of the Local Commission. Considering that the territorial scope of each LFC is the municipality (Law-Decree no. 164-A/97, 27 June 1997), the presence of representatives from local authorities is required, in the vast majority of cases. Although the scope for their initiative might seem limited, their closeness to citizens is extremely important and is considered a crucial factor in the implementation of this programme.

In the social domain, it is also important to stress that several municipalities have established facilities, such as kindergartens, workshops for youngsters, and day centres for the elderly.

In the area of education, several projects are being implemented in schools, usually where high percentages of students derive from ethnic minorities. The initiatives aim to promote multicultural education and to fight racism with projects supported by the Ministry of Education and in cooperation with the Portuguese UNICEF Council. Among them, the project 'In favour of the Minorities', being developed in the municipalities of Amadora, Oeiras and Setúbal, is part of the wider programme 'Digital Cities' set up by the Ministry of Science and Technology (MST) to fight info-exclusion among the migrant communities in the LMA. In partnership with the ACIME, immigrants' associations located in the LMA presented projects to the MST that included the installation of multimedia computers (by an IT research institute, INESC) connected to the Internet, allowing youngsters to have easier access to information and receive training in the use of computers. In this first phase, seven immigrants' associations were selected by the ACIME to participate in this initiative. Considering that four of them did not have the proper facilities to host the trainees and the hardware, the three other municipalities were included in order to provide the physical infrastructure. Another project worth mentioning is being implemented by Loures municipality and is called APELARTE - Multicultural Education (GARSE, 2000). It is a personal and collective enhancement programme aiming to promote social integration and active citizenship through educational and training initiatives. Teenagers attend free classes for photography, African dance, traditional music, chess, drama, and so on. They can also play football and volleyball and have tutorials to do their school homework. According to the Agency for Religious and Social Issues (GARSE), which fosters the integration of immigrants and ethnic minorities in Loures, this is an educational and training project with social, leisure and pedagogical goals to help youngsters build life projects and choose future professions.

In a third level of priorities for local authorities, one can find initiatives related to culture, active citizenship and support for immigrants' associations. In terms of cultural activities, all municipalities support and organise festivities, music, dance and gastronomic festivals and national day celebrations. Dance groups also receive support from local authorities, and among them Batoto Yetu - Portugal is a well-known African dance group of national repute. It was founded in 1996 with the support of the Luso-American Foundation for Development (FLAD) and is similar to the original American project involving children from deprived New York neighbourhoods. The main goal is to develop self-esteem, discipline and perseverance among the youngsters, and every member has to attend school (Baganha et al., 2000). Their headquarters are in Oeiras municipality, which supports their activities strongly. Another initiative worth 
mentioning is the Hip-Hop and Graffiti Nucleus in Vale da Amoreira in Moita municipality. Graffiti competitions and hip-hop festivals promoted by the local authorities mobilise youngsters around this kind of urban art and music.

In 1997, the Lisbon municipality set up a Centre of Multicultural Resources. It is a forum for cultural and information exchange among people of different cultural backgrounds living in Lisbon (Portuguese, African, Gypsy, Indian, etc.). The Centre has a library, an exhibition area, multimedia computers, Internet classes and courses on multiculturalism, citizenship, Creole, and so on (Câmara Municipal de Lisboa, 2000).

The municipality of Amadora publishes a newsletter - Infoculturas - with information about activities developed among the migrant communities and ethnic minorities (Câmara Municipal da Amadora, 1999).

The most frequent initiatives in terms of active citizenship in the LMA have to do with the organisation and promotion of workshops on the rights and duties of immigrants and ethnic minorities, in close cooperation with the ACIME. In these workshops, civil servants working directly in the neighbourhoods usually give their opinion and advice on how to conduct further action to promote active citizenship among foreign citizens. One of the last initiatives took place in Sintra municipality, and in cooperation with the ACIME, two workshops on the rights, obligations and duties of immigrants and minority ethnic groups were organised.

Several local authorities develop partnership agreements with immigrants' associations, and these often diffuse useful information for immigrants. NGOs and the Catholic Church are also important to the development of cooperation with these associations. When the associations are non-existent or not very active, NGOs can be responsible for the projects presented to the local authorities.

After analysing the answers to our questionnaires, it was possible to understand that there are four types of relationship between local authorities and the associations. The 'proactive municipality' plays an active role and invites associations to put projects forward - these municipalities are Oeiras, Amadora and Sintra. The municipalities of Lisbon, Seixal, Moita and Barreiro can be considered the 'reactive type' because associations often take the initiative and present projects to the local authorities. Three municipalities can be included in the 'non-preponderance' group because there is an interactive relationship in which associations and local authorities present projects to each other - such as Almada, Setúbal and Loures. The 'occasional' includes Vila Franca de Xira, Cascais and Montijo, because there are only occasional contacts between the two parties and it is difficult to define who is more active.

This difference in procedures is not only due to the willingness and capacity of local authorities, but also to the number, strength and leadership capacity of associations. In municipalities where a consolidated associative movement is found, local authorities put their trust in associations and thus they have a more active role. However, some local authorities prefer to present initiatives and programmes to associations who, after an exchange of ideas and opinions about the project, become partners. In other municipalities with a very incipient associative movement, contact between the two parties is only sporadic.

On a lower level of priority for local authorities one can find initiatives related to labour market and training. The majority of the courses have European funding and are organised in close cooperation with the Institute of Employment and Training (IEFP). Several courses are offered to those wanting to improve their working skills. Again, this is not exclusively for immigrants but for everybody living in municipalities. Because many trainees only go to training classes for the attendance wage, some local authorities support them to set up small firms, giving continuity to the training programme (Loures and Vila Franca de Xira). In this last municipality they are also persuaded to attend night classes to improve their educational level. The low attendance rate at training classes is due to the low social prestige some courses enjoy, for example gardening, cooking and masonry, and therefore they are not attractive for young people.

Decentralised cooperation with the sending countries, establishing networks of twin cities, 
is also one of the initiatives at the bottom of the list. All municipalities in the LMA have twincities agreements with municipalities in other countries, and these often correspond to the home towns of immigrants. Through these treaties, cooperation is set up to design technical projects for electricity and water supply, to give training in Portugal and in loco, to donate construction materials, books, surgical instruments and ambulances, and to implement student exchange programmes. The municipalities of Loures and Oeiras have been developing a remarkable programme, mainly with Cape Verdean (Mindelo, Maio), Mozambican (Matola, Benguela) and Indian (Diu) cities.

\section{The Institutional Relationship Between Local Authorities And Immigrants}

Considering the importance and variety of challenges faced by immigrants and ethnic minorities, several municipalities in the LMA have been developing different institutional relationships with the communities. During the interviews we were able to identify two different types of relationship. On the one hand, the institutional contact between local government and migrant communities may be formalised through consultative councils and specific agencies working with immigrants. On the other hand, there are several municipalities that, although recognising the ethnic and cultural diversity of migrant communities, base their relationship on an attitude of equal treatment of all citizens, independent of their ethnic, social or religious origin.

The different approaches result from several factors, among which the following are significant: (1) the varying numbers of foreign citizens living in each municipality; (2) the political complexion of various municipalities; (3) the influence, maturity and dynamics of immigrants' associations; and (4) the personal attitudes of local political leaders.

Lisbon is a municipality that fits into the first category. In 1993 local authorities decided to establish the Municipal Council of Migrant Communities and Ethnic Minorities, with the goal of ensuring the participation of associations in activities that promote the cultural enhancement and development of migrant communities and ethnic minorities.

In a similar process to Lisbon, in 1994 the Amadora municipality established the Municipal Council of Ethnic Communities and Immigrants, functioning as a consultative agency to promote the participation of immigrants and ethnic minorities in the definition of policies. This initiative shows that the local foreign communities can be enhanced, while simultaneously respecting the right to be different. There is also a municipal agency working in close contact with the associations to give logistical and technical support to projects that enhance cultural, social, health and training issues among the communities.

In Loures, a similar consultative council for migrant communities and ethnic minorities is being planned, although municipal support is already being given by the Agency for Religious and Social Issues set up in 1993. It provides logistic, technical and financial means to associations with projects developing the cultural and social features of Portuguese and non-Portuguese societies (Esteves and Caldeira, 2001).

In Sintra, integrated in the health and social support department, one can find an Agency to Support Minorities that works in close cooperation with NGOs (Civitas, for example) and the Catholic Church. Since their establishment in 1999, they have been gathering information on the number of associations, the needs and potentialities of communities, so that further work with the residents can be properly developed.

The other municipalities fit best into the model of non-differentiated treatment. As we were told in the interview carried out in Moita municipality, it is important to avoid reinforcing the idea that being an immigrant or a member of a minority ethnic group is a condition that needs a special relationship with the local authorities. To give one example, when the local market was being planned, vendors were asked to give their opinion about the architecture of the building. As some vendors are Portuguese and others have an African origin, just like the clients, the architects were informed of what kind of vending stalls were preferred. Thus, the features of this market correspond largely to the wishes of those selling and shopping there. 


\section{CONCLUDING REMARKS}

As Castles and Miller (1998) pointed out, when one talks about immigration control, what is at stake is not the entry movements, but rather the permanence of certain segments of foreigners in the territory. Regulating international migration means, above all, control of the consequences of entry and mainly the consequences of permanence of people coming from economically weaker societies with strong demographic growth, and control of the consequences resulting from the ethnic diversity in the host countries.

The concept of a Fortress Europe based on 'zero immigration' from other countries has been revealed to be totally inefficient, preventing the establishment of a common immigration policy regulating the entry of non-EU citizens and the full integration of immigrants into the host societies. Restrictions to legal immigration have had the opposite effect, inducing the development of clandestine immigration, associated more and more with international trafficking networks.

Portuguese immigration policy, mainly after the mid-1990s, has been trying to balance restrictions to entry of immigrants resulting from the Schengen Agreement, with the application of institutional conditions favourable to immigrants' integration. Moreover, Portuguese authorities have been trying to influence their EU partners in order to adopt a more open immigration policy, facilitating documented immigration, and thus reducing the pressure of illegal immigration.

Based on research carried out by work groups on immigration issues, the Tampere European Council in 1999 adopted a set of guidelines opposing the idea of Fortress Europe, instead promoting the establishment of partnership agreements with sending countries in order to aid their development, improved management of migration flows particularly in the fight against illegal migration, and fair treatment of foreign nationals. However, it has not been possible until now to establish common directives about these issues.

The abolition of internal border control in the EU implies a major coordination effort among the member states towards greater openness to documented immigration, reinforcement mechanisms fighting illegal entries, harmonisation of penal law in terms of international labour trafficking, and a collective effort to reduce migratory pressure from origin countries. Although the increase of legal migration does not per se solve the problem of demographic ageing of the European population, or answer all the needs of the employment market, we believe the adoption of a more open and flexible immigration policy is essential to reducing clandestine immigration. However, to achieve good results, all agents involved in the migratory systemgovernments, immigrants' associations, trade unions, employers' associations and other regional and local institutions - must collaborate with each other.

Besides all the measures to fight clandestine immigration, another essential factor in immigration policy is to establish conditions to ensure the complete integration of immigrants in the host society. The concession of long-term residence permits is an essential element in fighting discrimination. In Portugal, although one can say that from the institutional viewpoint there are favourable conditions for the integration of immigrants, in day-to-day practice many are exploited by unscrupulous employers, marginalised or socially excluded due to lack of documents, or simply because they do not know their rights. In daily social practice, the association often made between immigrants and ethnic minorities, and between non-white and foreigner, reveals a collective discriminatory attitude in a society with little openness to difference, mainly among the elderly and less educated citizens (Rosa et al., 2000).

Unlike other more developed European countries with deeper-rooted immigration traditions, in Portugal there are no political parties or ultra-nationalist movements with xenophobic or racist features. However, the existence of skinheads and clashes between Portuguese and foreign youngsters of different ethnic origins, mainly in the Lisbon area, are clear signs of an increase in racial tension and are cause for growing concern among politicians and citizens alike.

Managing the ethnic and social diversity of future societies presents new challenges to 
citizenship. In this framework, local authorities have an essential role to play. A bottom-up approach supported by the empowerment of civil society at the local level is probably the key to avoiding the operation of social exclusion processes. Local authorities have to work with all the citizens, on an equal basis, independent of their nationality or ethnic background, and not just for the citizens. They should be able to voice their questions concerning the life of the municipality, so that policies can be relevant to all those living in the municipality. This is more important than ever, not only because society is becoming socially more diverse, but also because its ethnic composition is more varied.

\section{NOTES}

(1) In 1997 the number of foreigners with residence permits living in the Southern European countries represented less than $2 \%$ of their population: $1.5 \%$ in Italy, $1.4 \%$ in Spain, $1.5 \%$ in Greece and $1.7 \%$ in Portugal (IOM, 2000).

(2) The first governmental agreement among the five foundation countries (France, Germany, Belgium, the Netherlands and Luxembourg) was signed on 14 July 1985 . Italy signed the agreement on 27 November 1990, Spain and Portugal on 25 June 1991, Greece on 6 November 1992 and Austria on 28 April 1995. Full implementation of Schengen Agreements (1985 Agreement and 1990 Convention) has started from 1 July 1995 after an initial three-month period of application, by seven member states (Germany, Belgium, Spain, France, the Netherlands, Luxembourg and Portugal). The Schengen area has gradually included all EU states, except the UK and Ireland. Despite having signed the agreements, Italy and Greece were not immediately admitted because they did not fulfil all the necessary requisites. Italy joined the group in 1997 and Greece in March 2000. Denmark, Finland and Sweden signed the agreement on 19 December 1996. However, Denmark only applied the dispositions on 25 March 2001. Norway and Iceland, non EU-members, signed a co-operation agreement with the Schengen area countries on 19 November 1996.

(3) Nationals from Angola, Mozambique, GuineaBissau and S. Tome and Prince can neither vote nor be elected because the attribution of the rights to vote and to be elected is only done under condition of reciprocity.

\section{REFERENCES}

Albuquerque R, Ferreira LE, Viegas T. 2000a. O Fenómeno Associativo em Contexto Migratório. Duas Décadas de Associativismo de Imigrantes em Portugal. Celta Editora: Oeiras.

Albuquerque R, Ferreira LE, Viegas T. 2000b. O Associativismo dos Imigrantes em Portugal. In Janus 2001 - Anuário de Relações Exteriores. Lisboa: Público e Universidade Autónoma de Lisboa: Lisbon (eds); 198-199.

Arango J. 1998. Immigrants in Europe: between integration and exclusion. In Metropolis International Workshop, Proceedings. Luso-American Development Foundation (ed.): Lisbon; 231-256.

Baganha M, Ferrão J, Malheiros J. 1999. Immigrants and the labour market: the Portuguese case. In Metropolis International Workshop, Proceedings. Luso-American Development Foundation: Lisbon; 89-120.

Baganha MI, Malheiros J. 2000. Imigração Ilegal em Portugal: Padrões Emergentes em Inícios do século XXI. In Janus 2001 - Anuário de Relações Exteriores. Público and Universidade Autónoma de Lisboa: Lisbon (eds); 190-191.

Baganha MI, Marques JC, Fonseca G. 2000. Is an Ethclass Emerging in Europe? The Portuguese Case. Luso-American Foundation (ed.): Lisbon.

Câmara Municipal da Amadora 1999. Projecto Educar para Integrar (2000/2001) Pelouro das Minorias Étnicas e Comunidades Imigrantes: Amadora.

Câmara Municipal de Lisboa 2000. Relatório de Actividades de 1999. Conselho Municipal das Comunidades Imigrantes e Minorias Étnicas: Lisbon.

Castles S, Davidson A. 2000. Citizenship and Migration - Globalization and the Politics of Belonging. Macmillan: London.

Castles S, Miller M. 1998. The Age of Migration. International Population Movements in the Modern World (2nd edn). Macmillan: London.

Dupraz P, Vieira F. 1999. Immigration et Modernité: le Portugal Entre Héritage Colonial et Intégration Européenne. Pôle Sud 11: 38-54.

Esteves A, Caldeira MJ. 2001. Reinventing cultures: the contribution of the Cape Verdean community to the cultural dynamics of Lisbon. In The Mediterranean Passage. Migration and New Cultural Encounters in Southern Europe, King $\mathrm{R}$ (ed.). Liverpool University Press: Liverpool; 95-118.

Faulks K. 2000. Citizenship. Routledge: London.

Fonseca ML. 2000. The geography of recent immigration to Portugal. In Geography, Environment and Development in the Mediterranean, King R, De Mas 
P, Beck JM (eds). Sussex Academic Press: Brighton; 137-155.

Frangouli-Papantoniou M. 1998. Modes of insertion of illegal migrants on the labour market: the case of Greece. In Metropolis International Workshop, Proceedings. Luso-American Development Foundation: Lisbon (ed.); 121-140.

GARSE 2000. Projecto Piloto APELARTE: Educação Multicultural. Paper presented at the Congresso dos Poderes Locais e Regionais da Europa, Innsbruck.

IOM 2000. World Migration Report. International Organization for Migration, United Nations.

Iosifides T, King R 1996. Recent immigration to Southern Europe: the socio-economic and labour market contexts. Journal of Area Studies 9: 70-94.

King R. 2000. Southern Europe in the changing map of migration. In Eldorado or Fortress? Migration in Southern Europe, King R, Lazaridis G, Tsardanidis C (eds). Macmillan: London; 1-26.

King R, Rybaczuk K. 1993. Southern Europe and international division of labour: from mass emigration to mass immigration. In The New Geography of European Migrations, King R (ed.). Belhaven: London; 175-206.

King R, Black R (eds). 1997. Southern Europe and the New Immigrations. Sussex Academic Press: Brighton.

King R, Lazaridis G, Tsardanidis C (eds). 2000. Eldorado or Fortress? Migration in Southern Europe. Macmillan: London.

Lapeyronnie D. 1992. Immigrés en Europe. Politiques Locales d'Intégration. La Documentation Française: Paris.

Leitão J. 2000. Direitos dos Imigrantes em Portugal. In Janus 2001 - Anuário de Relações Exteriores. Público e Universidade Autónoma de Lisboa: Lisbon (eds); 176-177.

Machado FL. 1992. Etnicidade em Portugal Contrastes e Politização. Sociologia - Problemas e Práticas 12: 123-136.

Malheiros J. 1998. Immigration, clandestine work and labour market strategies: the construction sector in the Metropolitan Region of Lisbon. In Immigrants and the Informal Economy in Southern
Europe, Baldwin-Edwards M, Arango J (eds). Frank Cass Publishers: London; 169-185.

Malheiros J. 2000. Urban restructuring, immigration and the generation of marginalized spaces in the Lisbon region. In El Dorado or Fortress? Migration in Southern Europe, King R, Lazaridis G, Tsardanidis C (eds). Macmillan: London; 207-232.

Marques MM, Santos R, Ralha T. 1999. Immigrants' Participation in Civil Society in a Suburban Context: Between "Top-down Activation" and "Bottom-up Mobilization". Working Papers 12. Socinova: Lisbon.

Mingione E. 1995. Labour market segmentation and informal work in Southern Europe. European Urban and Regional Studies 2: 121-143.

Montanari A. 2000. Demography, international migration and sustainable development in the Euro-Mediterranean region. In Geography, Environment and Development in the Mediterranean, King R, De Mas P, Beck JM (eds). Sussex Academic Press: Brighton; 99-116.

Penninx R. 2000. Participation of Immigrants through their Organizations: Political Visions on Multiculturalisms and their Implications. Working Papers 14. Socinova: Lisbon.

Pugliese E. 1993. Restructuring of the labour market and the role of Third World migrations in Europe. Society and Space 11: 513-522.

Reyneri E. 1998. The role of the underground economy in irregular migration to Italy: cause or effect? Journal of Ethnic and Migration Studies 24: 313-331.

Ritaine E. 1999. Enjeux Migratoires en Europe du Sud - Présentation: Convergence des Normes, Differentiaition des Débats? Pôle Sud 11: 3-7.

Rosa MJV, Marques MM, Oliveira C, Araújo F, Oliveira N, Dias N. 2000. International migrants: from facts to concepts. Paper presented at the 5th International Metropolis Conference, Vancouver, 13-17 November.

Ruivo F. 2000. Poder Local e Exclusão Social. Quarteto Editora: Coimbra.

Solé C. 2001. El impacto de la immigracion en la economia y en la sociedad receptora. Anthropos: Barcelona.

Soysal Y. 1994. Limits of Citizenship. University of Chicago Press: London. 